\title{
The journey of C.T. Ramage through the Cilento in the first half of the nineteenth century, between geography and history of an 'unknown' land
}

\begin{abstract}
Many travelers-writers have described the characteristics of the areas visited from a critical point of view, with wit and sense of observation. One of the most significant and unknown works concerning this literary current is the tale of the trip from Paestum to Policastro made in 1828 by C.T. Ramage: his sketchbooks are not only a description of the evidence of the past and of the archaeological remains of the Ancient Greece, but a small geo-history of the Cilento (shortly before its insurrection of that same year), as the first stage of a journey that returns a fresco of the South of Italy as it was before the process of Italian unification, respect to its agricultural landscapes, customs and dietary habits, attitudes, superstitions, society, culture, religious and political affairs, comparable with the present context of the same territories.
\end{abstract}

Keywords

Perceptions $\cdot$ representations $\cdot$ narratives $\bullet$ travels

(C) University of Warsaw - Faculty of Geography and Regional Studies

\author{
Silvia Siniscalchi \\ Department of Humanistic Studies \\ University of Salerno, Italy \\ e-mail: ssiniscalchi@unisa.it \\ Received: 16 November 2018 \\ Accepted: 24 January 2019
}

Introduction

"We are like dwarfs on the shoulders of giants": so wrote Bernard of Chartres in the twelfth century (Metalogicon, III, 4). That's a metaphor which intends to express the dependence of the modern culture on the ancient, and it's very adequate for the rediscovery of the important knowledge assets of the Grand Tour's literature. Through long stays in Europe and in Italy, many traveller-writers have described the characteristics of the areas visited from a critical point of view, highlighting their strong and weak elements with great wit and sense of observation. One of the most significant and unknown works concerning this literary current is the tale of the trip from Paestum to Policastro, made in 1828 by Craufurd Tait Ramage: his sketchbooks are not only a description of the evidence of the past and of the archaeological remains of Ancient Greece, but a small geo-history of the Cilento (shortly before its insurrection of that same year), as the first stage of a journey that brought back a fresco of the South of Italy, as it was before the process of Italian unification, with respect to its agricultural landscapes, customs and dietary habits, attitudes, superstitions, society, culture, religious and political affairs. So Ramage's writings try to bring into focus such important aspects of the anthropic and natural geographical landscapes traversed, and they can help us, inductively, to reconstruct their social and economic structure. Ramage's trip therefore is an aesthetic and geographical description founded on a subjective and objective spirit, in which influences caused by observation of natural beauty are not limited to mere aesthetic contemplation but, through culture and skills of observation, they give voice to the territory and its testimonies. Therefore, in this literary work the fundamental parts of a geo-historical process, whose consequences are discernible today, are evident in the critical points of Southern Italy, and of Cilento in particular, according to the same dynamics which were already widely and effectively described two hundred years ago.

Travel literature, territory and geography

Over the past fifty years, the areas of geographical research have expanded, with an articulation of the idea that space is no longer only measurable with Euclidean geometric coordinates. In particular, the cognitive sciences and functionalist theories have led geographers to also study the "invisible" aspects of landscapes (Ruocco 2010), according to precise "grammars" (Vallega 2004). Therefore, from the 1990s onwards in the Italian scientific context, we can find a relationship between geography, literature, historic essays and criticism of travel literature. So, the research tools of geographers, together with those of sociologists and psychologists (cognitive and social), thus gave rise to "a new study and research paradigm which considers the travel experience and literary productions as useful not only to reconstruct the 'geographies of the past' and the contemporary 'history of geographic knowledge'” (Scaramellini 2008, p. 39), but also to try to establish their respective contexts of reference. These, for the most part, revolve around the concept of landscape, understood as "space of artistic perception", "container of myths, dreams, emotions" (Tosco 2007, p. 85) in an evocative dimension that - observes Quaini (2006) - raises more attractiveness than the strictly analytical aspects of the geography. So, since a long 
time ago, in addition to "classical" studies in travel literature (in a descriptive and historical-humanistic way), ${ }_{1}^{1}$ the need to experiment with more innovative and "syncretistic" investigations has been established, from wider points of view (such as aesthetic and symbolic). ${ }^{2}$

The literature of the Grand Tour, as an artistic, cultural and social matrix of production, ${ }^{3}$ lends itself well to this purpose, confirming the famous allegory of "dwarfs on the shoulders of giants" attributed to Bernard of Chartres (Metalogicon, III, 4). In fact, this particular kind of literature increases geographical knowledge and, at the same time, "contributes to the construction of the myth of the landscape, and that of Italy in particular" (Mazzetti 2008 [a], p. 343), producing images that have become constitutive of a well-recognised identity, ${ }^{4}$ cultural and territorial, rooted in real existing contexts, since even the places of myth, for the most part, "have a name, and correspond to real places" (Ferrari 2010, VIII, p. 386). In fact, the stories of the Grand Tour (spontaneous or commissioned by some publisher: Mazzetti 2008 [b]) in major European cities of the 18th and 19th centuries, ${ }^{5}$ although giving importance to an experience reserved for the sons of aristocratic families (followed by bourgeois, writers and artists), ${ }^{6}$ have undoubtedly the merit of telling the "physical, geological reality of the territory Italian, quite neglected until the second half of the eighteenth century" (Mazzetti 2008 [a], p. 342). It is certainly the case of valuable works such as the Voyage Pittoresque of the Abbot de Saint-Non and Goethe's Journey to Italy, but also of some minor writings (excluding those of a stylised and stereotypical character). ${ }^{7}$ Geographical-historical research on territorial conditions in the past few centuries can thus be aided greatly by some of these texts, appropriately integrated with other contemporary sources. ${ }^{8}$

\section{The Cilento, between collective imagination and geographical} reality

Through these reflections, this contribution, with the support of historical maps and some well-known texts from the $17^{\text {th }}$ to the $19^{\text {th }}$ century, follows the travel diary in the Kingdom of the Two Sicilies by Craufurd Tait Ramage (1868), ${ }^{9}$ minister of the Scottish church and professor of the sons of the English consul at the

${ }^{1}$ On the history of travel literature, refer to Fasano, online. Regarding geographical and historical studies on the topic, refer to Mozzillo (1992) and Scaramellini (2008). For wider reference bibliography, refer also to the online listings of the National Central Library of Firenze (http://grandtour.bncf.firenze.sbn.it/bibliografia).

${ }^{2}$ The geographical concept of "landscape" has experienced a lot of evolution in the last fifty years. In Italy, especially after the criticism of L. Gambi, it has merged into the concept of "territorialisation" (Raffestin 2005).

${ }^{3}$ Frémont (2007, p. 128 ), in turn, approaches the conception of art as "production of the real". But the idea of a profound interrelationship between reality and its artistic reproduction is above all philosophical, and goes back to the theory of Platonic mimesis (Siniscalchi 2012, p. 41, note 2).

${ }^{4}$ On the formation of a collective mentality of Italy's image through the "mirror" of the Grand Tour, refer to de Seta 1982

${ }^{5}$ The definition "Grand Tour" is attributed to Lassels (1670), who writes: "Travelling brings a man a world of particular profits [...] and no man understands Livy and Caesar, Guicciardini and Monluc, like him, who hath made exactly the Grand Tour of France, and the Route of Italy" (pp. 25-26).

${ }^{6}$ The British already adopted this custom during the $17^{\text {th }}$ century, followed by the French and Germans: Italy was the preferred destination for these trips, with its art cities, including Rome, Florence and Naples (Giosuè 2004, p. 7)

${ }^{7}$ Refer to Mazzetti 2008 [c], p. 351

${ }^{8}$ On this question, refer to the link between historical-geographical studies and the territorial planning evidenced today by Turri $(2002$, p. 8)

${ }^{9}$ The work of Ramage (Ramage in South Italy. The Nooks and By-Ways of Italy, Wanderings in Search of Its Ancient Remains and Modern Superstitions, Liverpoo 1868), translated in full and published in Italian (Ramage 1966) was recently republished, for the part concerning Cilento only (2013).
Court of the Bourbons of Naples. ${ }^{10}$ Animated by strong cultural interests towards Greco-Roman antiquities (and like almost all the Grand Tour travellers, attracted by Vesuvius too), Ramage travels through the Neapolitan domains "al di qua del Faro" (further on from the Faro); the reference is to the lighthouse of Messina: the main subdivision of the Kingdom was between its continental part (Royal Domains on this side of the Faro) and Sicily (Royal Domains beyond the Faro) and a small part of the Papal State. ${ }^{11}$ He thus drafts a fresco of the environmental, social, political and economic conditions of the pre-unitary South, only published in the form of correspondence in $1868,{ }^{12}$ when, as he himself explains, those "who favor the Constitution prevailed, while the supporters of the Bourbons, I am sure, have had a good lesson, with being subjected, at least in part, to the same pains and concerns that they inflicted on their opponents" (Ramage 2013, p. 27).

Leaving Naples in 1828, the real journey of Ramage starts from Cilento, a part of the ancient Lucania according to the geographical, erudite meaning of the time,$^{13}$ being part, from an administrative point of view, of the Districts of Vallo and Sala, in the province of "Principato Citra" [now province of Salerno], ${ }^{14}$ or west Lucania. ${ }^{15}$ Considered a closed world, with "traditions and customs of primitive mold", "the land of the sad", according to the definition of the Bourbon police, or "land of murderers and brigands, where violence was law anyway, the private revenge an undisputed principle" (Ramage 2013, pp. 49-50, 121), the "vast mountainous, and pleasant region of Cilento" [Ramage 2013, p. 38 (Fig. 1)], already disquieting because of its mysterious name (of late use but of ancient origin), ${ }^{16}$ the uncertain

${ }^{10}$ Born in 1803 in Annfield (Scottish county of Midlothian), Ramage graduated in Literature from the University of Edinburgh in 1825, immediately becoming preceptor of the youngest children of Sir Henry Lushington, baronet and consul of St. M. Britannica in Naples. Here he spent two years, until he made the journey through the Kingdom of the Two Sicilies in 1828 and then returned home, where he married, continuing his work as a tutor of the sons of high-ranking families and dedicating himself to literary activities, with the publication of different works. Appointed in 1841 as Deputy Director of the Wallace Hall Academy of Closeburn, in Dumfreisshire, he became District Judge of the same county (1848), receiving a degree in Jurisprudence from the University of Glasgow (1852). He died in 1878.

${ }^{11}$ After reaching Sapri, and from there, Calabria (Tyrrhenian and Ionian), the Scotsman crosses part of the Lucanian and Apulian coast to Taranto, then heads towards Gallipoli, to the south-east. Here he sets sail to go up the Adriatic, after having passed the Cape of S. Maria di Leuca, and subsequently visits Brindisi, Foggia and the Molise, returning to Naples at the end of June.

${ }^{12}$ Refer to Ramage 2013, p. 27. The notes are turned into a series of letters addressed to Mr. Morris Charles Jones, who had invited Ramage to tell him in writing of his experience between the cities of the south-western and south-eastern coast of Southern Italy. The literary escamotage is typical of odeporic literature, in which the narration of the path had to take place in direct form (Fasano online).

${ }^{13}$ Ramage reaffirms this, when, having arrived near Torchiara, he writes: "You have to know that Lucania is the name of that part of Italy in which I am now" (Ramage 2013, p. 58). In a study some years ago, Aversano (1983), through research of archival documents, has reconstructed the temporal and geographical process that, during the Middle Ages and the modern age, testifies the replacement of the ancient toponym of Lucania (minor) with that of Cilento.

${ }^{14}$ Refer to De Sanctis (1840). The Statistic of 1811 (De Marco 1988, p. 590) declares, however, that the district of Vallo, including the municipalities of "Vallo, Gioj, Torchiara, Castellabate, Pollica, Pisciotta, Torreorsaia, Laurino, Cammerota, and Laurito", is considered Cilento.

${ }^{15}$ Refer to Costituzione Politica del Regno delle Due Sicilie del 1820 [Political Constitution of the Kingdom of the Two Sicilies of 1820], Napoli 1848, p. 173, where we also read that the name of East Lucania denoted the Basilicata. For a wider discussion on the borders of Lucania over the centuries and on the origin of the name, see Antonini 1745.

${ }^{16}$ According to a customary but incorrect etymological explanation, the name "Cilento" would have meant related to area, deriving from cis-Alentum (i.e. territory on the right side of the river Alento, compared to Salerno or the Abbey of Cava de' Tirreni), an expression attributed to the Lombard or Benedictine-Cavens ruling class. It is really a place name (of pre-Roman origin), initially referring to a fortress placed on the summit of "Monte della Stella", or to the same relief (Aversano 1982 and 1983). According to a more recent interpretation by F. Astone (2012), the name could derive from that of an Etruscan divinity called precisely "Cilens". From a historical point of view, contrary to what was considered in the past by distinguished researchers (as Muratori 1739, p. 


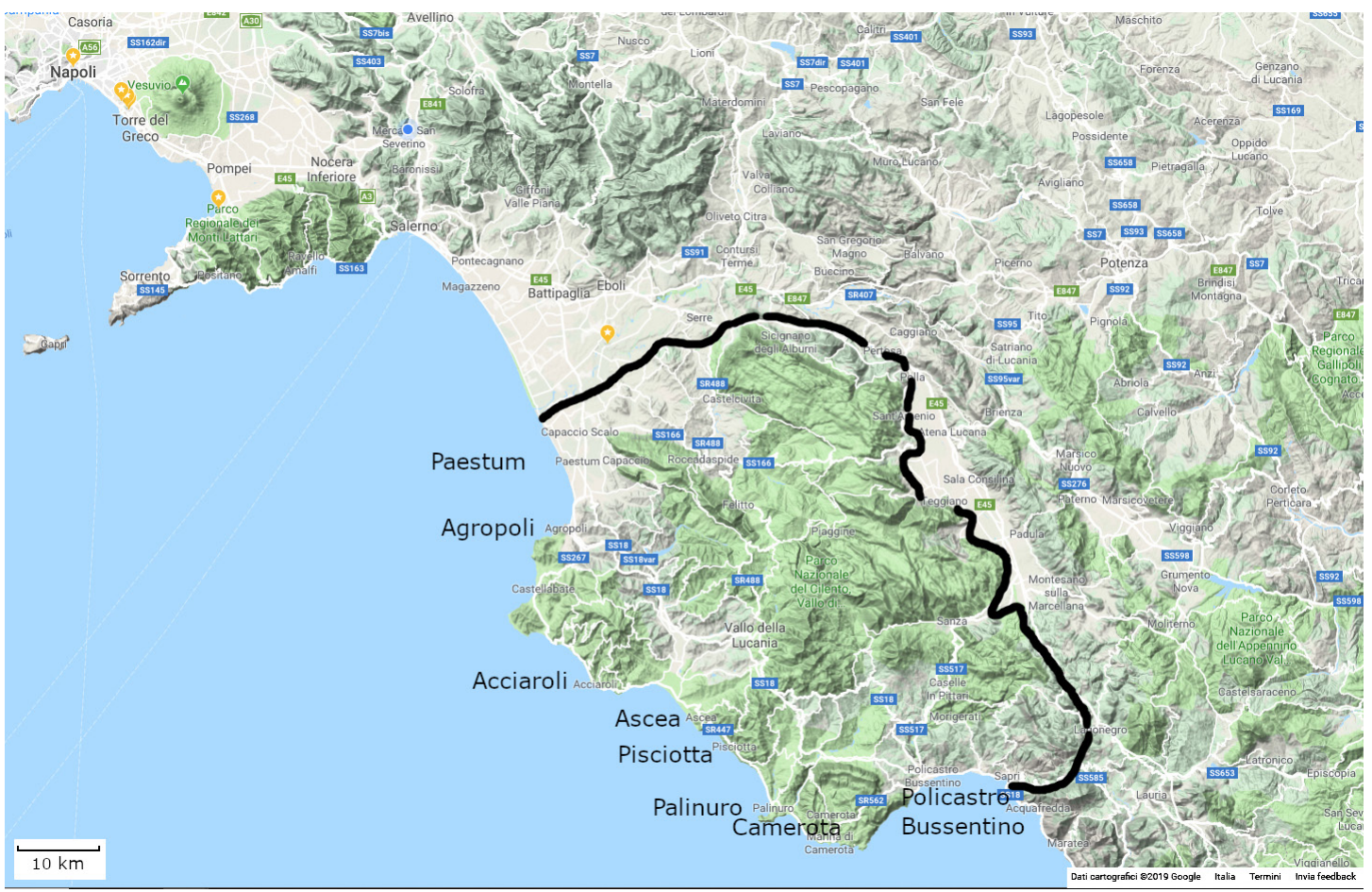

Figure 1. Delimitation of the Cilento area on Google Maps (black line introduced by the author).

The delimitation was implemented on the basis of a geographical definition of "Cilento" denoting the entire southern part of the province of Salerno, bordered to the north-east by the Marzano and Eremita mountains and, to the east, by the Vallo di Diano, starting from the plain to the left of the Sele river to the Gulf of Policastro.

boundaries, ${ }^{17}$ the wild landscapes, the centres perched on steep and rough peaks, often deserted villages on the coast (Siniscalchi 2008).

The travellers of the time did not pass Paestum (already difficult to reach: Capano 2012, p. 140), "because the road was insecure, haunted by brigands, full of dangers", ${ }^{18}$ as Macfarlane warned, and again, several years later, Lenormant, who considered "the places beyond Paestum as lands where it was reasonable to make a will before entering" (Mazzetti 2008 [a], p. 342). Nevertheless Ramage leaves, alone and on foot (according to the Grand Tour), ${ }^{19}$ equipped with geographical maps, ${ }^{20}$ notebooks,

1035), the oldest attestation of the name Cilento dates back to 994: recent studies recalls Aversano (1982, pp. 2-3) - prove that the document of the Codex Diplomaticus Cavensis which contains it (C.D.C., Tomo II, Doc. n. CCXXXI, p. 13), it is of 1072 . Its earliest evidence could date back then to the Actus Cilenti of 1034, with which at the same time began its transformation into a regional name (Aversano 1983, p. 80). The real regional name appears instead for the first time in 1692, in the map of the "Principato Citra" designed by F. Cassiano de Silva and then merged into the Regno di Napoli in prospettiva of Pacichelli (Aversano 2009, p. 15).

${ }^{17}$ For the delimitation and denomination of the area, see Mautone 1990, p. 227; Preziosi 1990; Aversano 1987 and 1989.

${ }^{18}$ D'Amico 2001, pp. 18-19. Paestum and its temples, the only visible sign of civilization in an otherwise degraded and swampy area, represented the "columns of Hercules" before which the Grand Tour travellers stopped, to resume the journey further south, heading towards the centres of the Sicilian part of the Magna Grecia.

${ }^{19}$ The journey on foot, of ancient tradition (religious, contemplative, philosophical, scientific), during the Grand Tour becomes a physical-spiritual educational practice, walking being a condition for bodily and psychic strengthening, through observation, meditation and "the dream". Concerning this, see Rousseau 2012

${ }^{20}$ It is very difficult to determine which maps Ramage had but they had to be detailed enough, since, as he remembers during his landing on the coast of Paestum, they report details on a great scale. They could have been Austrian or French maps, or drawn for the occasion by some local topographer or, again, some examples taken from the famous Atlante Geografico del Regno di Napoli [Geographical Atlas of the Kingdom of Naples] by G. Antonio Rizzi Zannoni, the first accomplished example of a unitary cartography of the Kingdom recently published (it was finished in 1808), straw hat and umbrella to protect himself from the sun (Ramage 2013, pp. 49-50 and p. 121). In a few days, going south and southeast, he reaches Agropoli, Torchiara, II Mercato (today Mercato Cilento), goes up the summit of Monte Stella and heads towards Porcili (today Stella Cilento) and Acquavella; he crosses the Alento valley and visits Velia with its abandoned castle of Castellammare della Bruca, then Ascea, Pisciotta, Centola, Palinuro, Camerota, San Giovanni a Piro, Policastro and Sapri (Fig. 2).

The Cilento through the Ramage journey

Through Ramage's diary, the disintegration of the relations between city and territory of the Bourbon Kingdom appears clearly, already taken over by G.M. Galanti, T. Monticelli and subsequently, by $\mathrm{C}$. Afan de Rivera. The story opens with the lively description of the path, riding in a calash from Naples to Salerno, already full of contrasts: the poverty of the population and magnificent landscapes (Ramage 2013, p. 38), chaotic traffic and deep bonds between community and environment, ${ }^{21}$ urban discontinuity and architectural beauty, ${ }^{22}$ miserable crops for people and livestock and rich farming for the affluent classes, ${ }^{23}$

commissioned by Ferdinando IV of Bourbon. Concerning this, see Valerio 1993 and Cantile 2013. For an overview of the Cilento cartography in the $19^{\text {th }}$ century, see also Aversano 2009, pp. 19-107.

${ }^{21}$ About Torre del Greco, periodically destroyed by Vesuvius, Ramage highlights the link between population and native soil, so deep "that the country has always been rebuilt in the same place, despite not a century passes that does not run new dangers because of the volcano" (Ramage 2013, pp. 39-40). It is a reflection that, developed at the beginning of the twentieth century by $\mathrm{V}$. de la Blache about the region as an "area of the kind of life", was recently revived by Turri (2004, p. 161).

${ }^{22}$ Ramage (2013, pp. 40-41) describes Nocera as "a very irregular town in the arrangement of houses" and, at the same time, admires its Church of Santa Maria Maggiore, "built on the ruins of a Roman temple".

${ }^{23}$ Ramage cherishes above all the rich citrus groves, vineyards and fruit trees of the Badia Cavense, famous for its power and its precious library. 


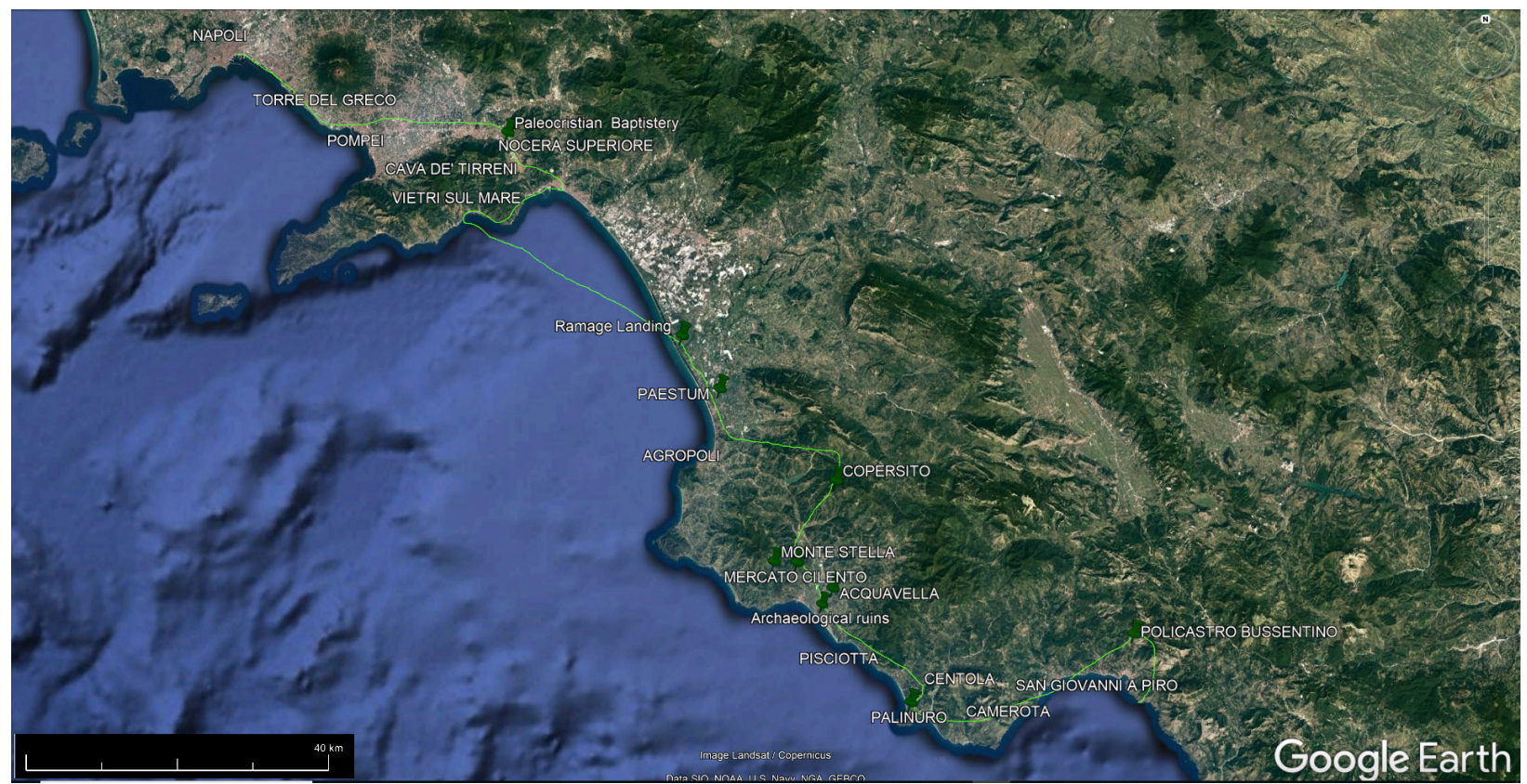

Figure 2. The main points of Ramage's travel through Cilento, highlighted on a Google Earth satellite image (author's underlining)

the decadence of the present and the prosperity of the past. ${ }^{24}$

The backwardness of the south area of Salerno seems to be even more evident: here, during the stop in Paestum - reduced to a small number of houses ${ }^{25}$ and afflicted by stagnant waters (Ramage 2013, pp. 48-49), with no trace of the old port, the ubication of which is still unclear (La Greca 2014, p. 57, and 2012, p. 62) - Ramage immediately experiences the environmental degradation and the poverty of the population, as the contemporary Atlas (Sheet 19) of Giovanni Antonio Rizzi Zannoni shows (Fig. 3).

The situation improves after the river Testene (deformation of the original name of "Pastena", as discovered by Aversano and as we can see in the cartography of the seventeenth century), ${ }^{26}$ with the climb to Mount Stella (1131m a.s.I.), from whose peak, distinguished by the ruins of an inhabited centre (which, as Ramage realises, are not those of ancient Petilia), ${ }^{27}$ it is possible

${ }^{24}$ The reference concerns Salerno and the blackened tops of its castle, also built by the Lombards during a period of wealth of the city, and its famous medical school.

${ }^{25}$ The Scotsman often finds himself staying in miserable inns, sleeping on wooden planks and straw mattresses, with meals based on black bread, sausage or fish soup, accompanied by a bad wine. The misery of the inland areas of the province of Salerno is marked by the "Statistica" del Regno di Napoli [Statistic of Naples Kingdom] (1988, p. 543 and pp. 581-582)

${ }^{26}$ Refer to Aversano, Siniscalchi, 2008, p. 77.

${ }^{27}$ Concerning this, see Greco 1975 , p. 84 . In addition to remembering what was revealed about the fortified centre of the Monte della Stella [Mountain of the Stella] by the scholars from the seventeenth to the nineteenth century (as G.N. Del Mercato, F.A. Ventimiglia, P. Magnoni, G. Racioppi) - for which reference is made to Acocella 1971 Aversano 1982 and Cantalupo 1989 - it is interesting to note that the tradition of studies that indicate a Petilia on the Mountain of the Stella in the ancient Cilento was protracted in the cartography of the nineteenth century, as shown by the reference to the Colli Petilini in the map titled "Pianta della Foresta di S. Francesco con i villaggi di Rocca e di San Martino e il convento di San Francesco" [Plan of the Forest of S. Francesco with the villages of Rocca and San Martino and the convent of San Francesco] (1810), by the land surveyor Felice Rizzo (see Aversano 2009, pp. 116-117). On Petilia, see also La Greca 2002, p. 409. Also interesting is the presence of the place name "Cilento" (next to the place name "Castel") in the $16^{\text {th }}$ century cartography (as La vera descrittione del Regno di Napoli di novo emendata et ampliata [The true description of the Kingdom of Naples, once again amended and extended] of S. Scolari, 1566; the Puglia piana, Terra di Barri, Terra di Otranto, Calabria et Basilicata [Plain Puglia, Bari's Land, Otranto's Land, Calabria and Basilicata] of G. Mercatore, 1589; the Regni Neapolitani verissima secundum antiquorum et recentiorum traditionem of A Ortelio, 1592). If the reference, as seems probable, is to the ancient centre called to enjoy an amazing view (Ramage 2013, p. 67), described by him with an appreciable geographical precision (which recalls, a century and a half in advance, that of the Italian geographer Aldo Sestini: 1963, p. 156). The environmental degradation re-emerges from the miasma of the Alento valley, swamped and without crops, after the rice fields had been the cause of even deadly diseases among the inhabitants. ${ }^{28}$ The dry river ${ }^{29}$ and the karst caves of Palinuro (more connoted by the myth than by real natural peculiarities) are disappointing for Ramage, contrary to the river Bussento (with its long underground path, caves and swallow hole), ${ }^{30}$ and to the marshes of Policastro (abandoned by rich people in the hottest months, for fear of malaria: Ramage 2013 , p. 133) and to the homonymous gulf, where the course of the river, returned to the surface several kilometres before, ends. The contrasts can still be seen in the hardened faces of the Cilentan citizens, grappling with a land that is unstable, not very generous, and torrid in summer (Yonder pp. 89-90), dispelling the belief in an idle southern population. Ramage, on its way to Torchiara and II Mercato - site of annual fairs, as the toponym attests experiences characteristics of the Cilentan territory that are still partly current: "small or mediocre-sized centres located on small

"Cilento"/"Castellum Cilenti" located on Monte della Stella, we must however recognise its purely historical-cultural character, since the position of place name on maps of the sixteenth century, mentioned in parentheses, is completely wrong (as indeed the locations of many other toponyms are incorrect: it shall only be seventeenth-century cartography, in particular that of G.A. Magini, that will return an acceptable geographical approximation regarding the locations of the centres)

${ }^{28}$ Concerning this, see G. Antonini (1745, Discorso III, p. 22), in which the number of deaths amounted to 4,000 .

${ }^{29}$ The circumstance is caused by the torrential character of the Alento, which has great flow rates during rainy and dry periods, more or less accentuated in those of drought. The springs are located on Mount Le Corne (894 m a.s.l.), within the National Park of Cilento and Vallo di Diano, while the delta is divided between the Tyrrhenian Sea, near Velia, and the towns of Ascea and Casal Velino.

${ }^{30}$ Ramage hypothesises a seismic cause for the underground path of the river, but in reality the underground hole is a particular type of karst gorge, defined as "epigenetic" and formed by rain infiltration into already fractured rocks. The cracks gradually become larger, until they reach the size of wells and caves, with developments of hundreds of metres, and sometimes of many kilometres, often crossed by underground torrents, just as in the case of Bussento (Aloia\&Guida online) 


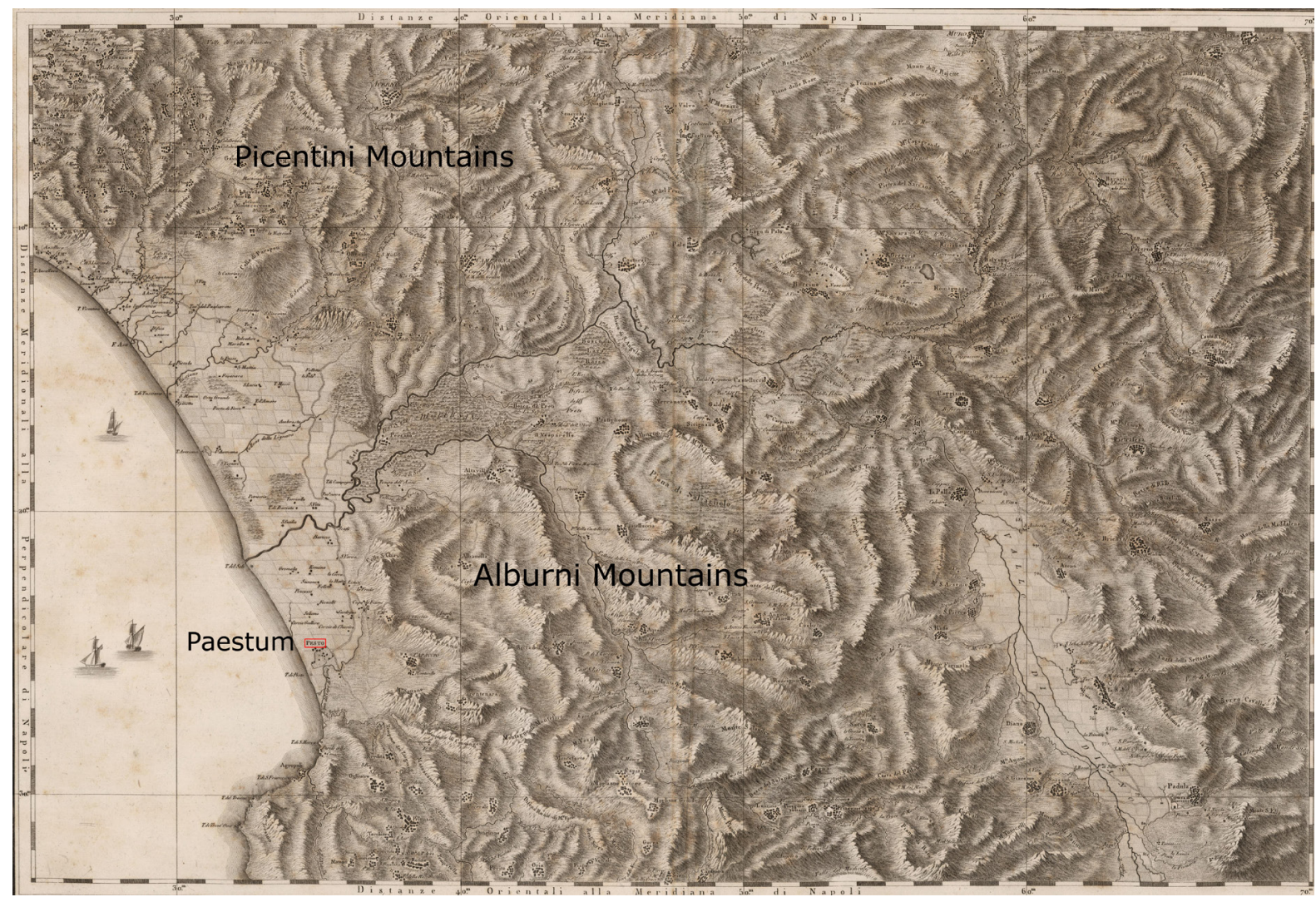

Figure 3. The Sele plain in an extract from Sheet 19 of the Atlante geografico del Regno di Napoli delineato per ordine di Ferdinando IV re delle Due Sicilie \& C. \& C. da Gio. Antonio Rizzi-Zannoni geografo di Sua Maestà e terminato nel 1808 [Geographical Atlas of the Kingdom of Naples outlined by order of Ferdinand IV King of the two Sicilies by Giovanni Antonio Rizzi-Zannoni, Geographer of His Majesty and completed in 1808]. Napoli, 1788-1812 (Firenze, Cartographic Archive, 11 th group, Order No. 28, archive folder 85, doc. 5). Scale 1:126,000. As can be seen from the drawing, the plain and the area of Paestum, bounded to the north from the southern foothills of the Picentini Mountains and south from the Alburni Mountains, are impaludate, with riverbeds without embankments and control, and extensive cultivation of poor quality (changes and additions are introduced by the author).

hills, large spurs and shelfs, or on extreme slopes of limestone reliefs", often dominated by "an ancient fortress or an old massive baronial palace" (Sestini 1963, p. 155), between blackened houses and uneven and rough roads (Ramage 2013, p. 59).

If "landscape modelled at a certain moment in history generally no longer works in later times" (Turri 2004, p. 171), the Cilentan one, persisting ancient forms and peculiar kinds of life (especially in the inland areas), has changed little, with positive (environmental and landscape preservation) and negative (economic-cultural backwardness, strong youth emigration) effects. ${ }^{31}$ This is also demonstrated by the presence of many monasteries and convents of different monastic orders (Ramage 2013 , p. 63), reduced in part to lay use after the French laws of subversion of feudalism. A circumstance that, despite the importance of the role of the religious for the development of the territory (especially during the Middle Ages), does not cause sorrow in Ramage, who experiences the superficiality and the rudeness of the local clergy, by now distant from the material and spiritual needs of the population (concerning this, see Ebner 1973 and 1982). It is precisely the hospitality and extreme poverty of this latter (Ramage 2013, pp. 80-81) that prompt him to grasp, with sympathy, a certain cultural affinity between Scotland and the Cilento (Yonder pp. 116-117), including brigands (Yonder p. 68).

\footnotetext{
${ }^{31}$ See Siniscalchi 2008, pp. 78-87. The Statistic of 1811 (1988, pp. 579-580) identifies precisely, in the isolation and absence of roads, one of the main reasons for the lack of civilization of some populations in the province of Salerno.
}

Visiting Porcile [sic] (Porcili) and crossing the valley of Acquavella (whose division between a few rich cultivated lands and many others left uncultivated (Yonder p. 75) reveals its economic depression), Ramage understands the real danger of the latter; he reassures himself however during the journey to Ascea and Sapri. An ex-official of Murat shows him the olive oil, corn, meats and cured meats, together with dried figs, as the finest food products in the area (Fig. 4), ${ }^{32}$ characterised by hills full of vineyards, olive trees, fig and oak trees, with houses surrounded by orange and lemon trees and lush apricot trees. On the other hand, the activities of the Ascea navy are not equally prosperous, because the fishermen are forced to yield half of their already modest earnings (derived mostly from the sale of anchovies and sardines) $)^{33}$ to the tax collectors of the government, with the salt tax. ${ }^{34}$ Ramage sees tax on the flour applied instead,

\footnotetext{
${ }^{32}$ The information - confirmed by the Statistic of 1811 (1988, p. 591, in which we read "The salamis of Cilento are perhaps the best of the Kingdom, such as hams, lards, etc.") - is reiterated by Sestini 1963, p. 154.

${ }^{33}$ The data is also in the Statistic of 1811 (1988, p. 591). Regarding the developments of the situation in the medieval and modern age, see Capano 2001, pp. 18-23.

${ }^{34}$ It was a government monopoly since the time of Frederick II of Swabia, with a significant profit for the state, which did not allow citizens to draw water from the sea and let it evaporate in the sun to obtain salt. Concerning this, see D'Arienzo 1991[a], pp. 3-24, and 1991[b], pp. 65-74. The salt tax, already lowered during the Napoleonic decade (see Colletta 1861, p. 30), is then reduced by a third by Ferdinando II in 1848 (see Pagano 1853, p. 25).
} 


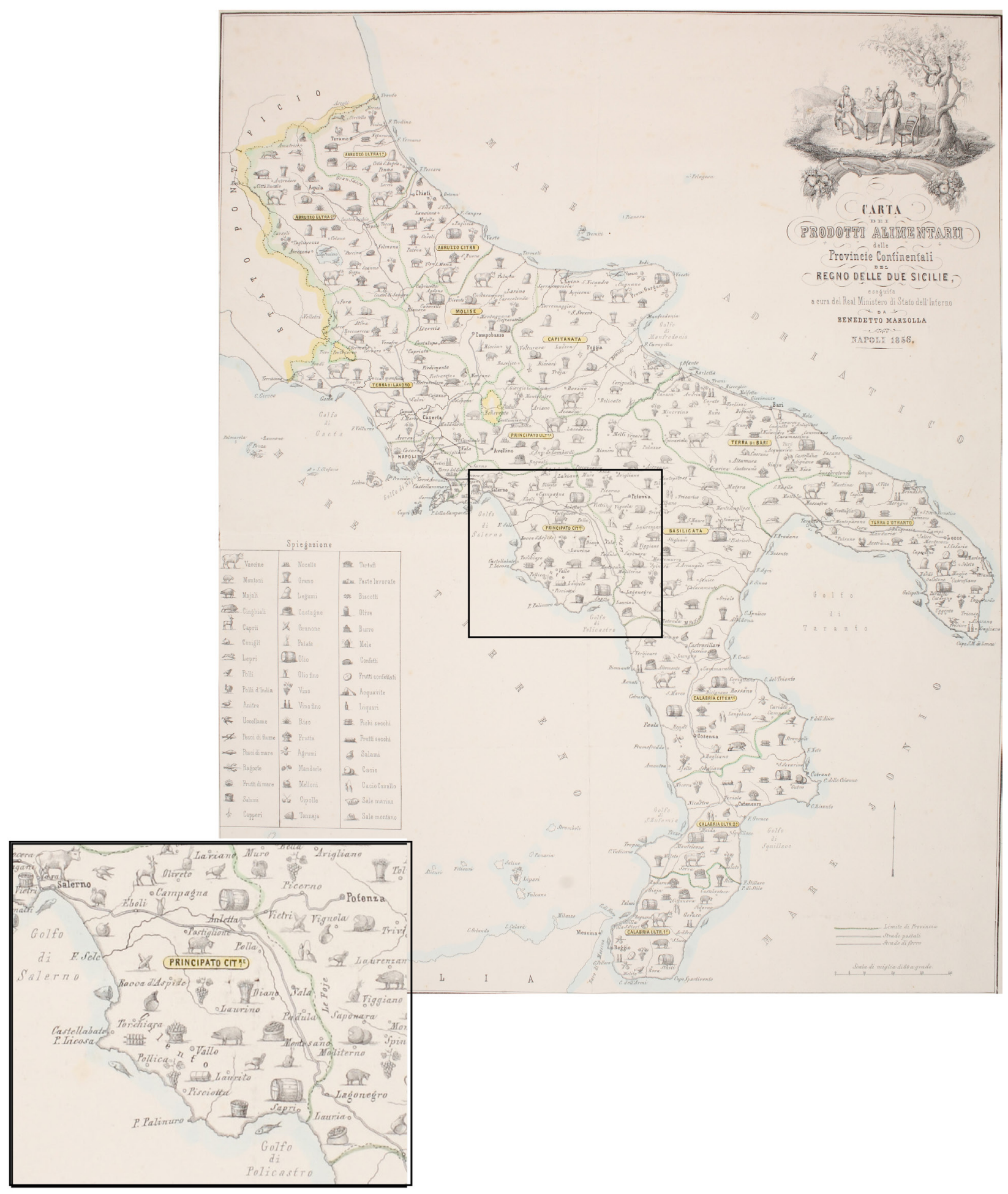

Figure 4. Benedetto Marzolla, Carta dei prodotti alimentari delle Provincie Continentali del Regno delle Due Sicilie [Map of food products of the Continental Provinces of the Two Sicilies Kingdom], Napoli 1856. Scale of 60 miles per degree (approximately 1:2,500,000). Also printed on silk, in very rare specimens, the map shows, through 51 figurative symbols, but without statistical data, an overall view on the distribution of raw materials and the various foods produced in the Kingdom of Naples. According to what Ramage writes, Cilento is characterised by the symbols of figs, dried fruit and wine near the coast, while, further inland, abundant salami, fresh fruit, pigs and, to the left of the Sele, corn. On the coast, on the other hand, we can see the symbols of a "Tonnaja" at the height of Agropoli and the capture of "sea fish" in the stretch between Agnone and Acciaroli (changes and enlargements are introduced by the author). 
near Centola, on the river Molpa (now Lambro), ${ }^{35}$ in one of the many parish mills controlled by the Bourbon government where the farmers had to bring the grain to grind.

Ramage is even more impressed by the "security card", an annual renewal document that is obligatory for all the citizens of the Kingdom (but "almost unnoticed by the rich"), which they must wear (on pain of imprisonment). Nonetheless, in reference to this, the diary does not express negative evaluations (except indirectly: Yonder p. 103): Ramage, a foreigner travelling in the Kingdom of Naples at the end of the 1920s, knew he had to be careful.

A warranted precaution, considering the anti-government sectarian movements, ${ }^{36}$ the role played by the Cilento in the revolution of $1799^{37}$ and the bloody revolt that broke out between the months of June and July of that same year, $1828 .^{38}$ Ramage experiences this nervous climate in particular at Pisciotta (an exMasonic Lodge) and in Camerota, where he realises he should be wary, while at Policastro he finds an incandescent situation, both among the inhabitants and the Bourbon guards, looking for "certain unfortunate Carbonari" chased "almost like wild beasts" (Ramage 2013, p. 132). So he has the opportunity to notice an emblematic psycho-social trait of the Cilentans, bestowed with personal courage but wary and incapable of "giving life to an organized resistance" (Yonder p. 132). The suspicions of local authorities about him are also born of his (unintentional) meetings with some revolutionaries, including Don Teodosio De' Dominicis, owner of the lands on which the ruins of Velia stood, and Ramage's guide during the visit to the visible remains of the ancient city, at that time still buried. ${ }^{39}$ The visit is an important moment of the journey, because Ramage describes what was left of ancient Velia ${ }^{40}$ - the walls, a cistern, the tombstones and the medieval ruins of Castellammare della Bruca (as Velia was called during the Middle Ages) ${ }^{41}$ - before the excavations of

\footnotetext{
${ }^{35}$ Capano (2012, p. 158, note 61) on the meaning of "Molpa" - which should indicate, as pointed out by A. Cinque (https://agerola.wordpress.com/2012/02/04/un-antichissimotema-mediterraneo-allorigine-del-toponimo-amalfi/), a depression of the ground (from whose "breast", "concavity", "chasm": Alessio 1958; Camporeale 1961, pp. 219-231) and Lambro (from lama, i.e. swamp, puddle), hypothesises that both place names recall the presence of marshes and swampy concavities, considering their presence in the Lombardy plain (Lambro) and in that of the Po river (Melpum), near marshy areas, and the affinity of Molpa with the hydronyms "Melpes" and "Melpis" of central-southern Italy.

${ }^{36}$ Indeed, for this reason, Ramage had obtained several letters of recommendation and the issue of a special passport before leaving, thanks to the help of General Carlo Filangieri, Prince of Satriano (see Ramage 2013, p. 25).

${ }^{37}$ Concerning this, Carucci (1937), remembering that the revolt in the Cilento of 1799 , often violent, caused the birth of the successive movements of 1828 and 1848 , highlights that it had not been a popular revolt, because it was animated by galantuomini [gentlemen], landowners who opposed the Bourbon monarchy. This latter, "among the most enlightened in Europe in terms of the reforms, before the French Revolution" ( $p$. 168), was initially loved by the people, since, with a series of reforms, it was "slowly canceling the privileges of the nobles and ecclesiastics, and had distributed to those without properties many lands taken from churches and others already constituting the state property, usurped and now reinstated" (p. 166). The French decade, however, changed things: in a few years Napoleon, with the laws on the end of the feuds, emptied "of its best content the Bourbon Monarchy, which survived as well, but not more popular. He had to rest on the gentlemen, often, even his ministers agreed with the democrats. Ferdinando IV and the kings who succeeded him always wanted the good of the people, but they were no longer the monarchs of it. And so their destiny was marked" (p. 168). Concerning the main protagonists of the Neapolitan revolution in Cilento, see Armone Caruso, 2000.
}

${ }^{38} \mathrm{As}$ for the failed revolution in the summer of 1828 by the secret society of the Filadelfi, developed within the Carboneria, and the violent repression that followed it, see Oliva 2012, pp. 201-202.

${ }^{39}$ De Dominicis (see Ramage 2013, p. 92 and after), a member of the sect of the White Pilgrims - one of the many filiations and transformations of the Carboneria after the revolts of 1821 (see Schiarini online) - was shot in 1828, having taken part in the anti-Bourbon conspiracy. The sentence accused him of "a meeting with a stranger unknown until now" (Galotti, Galzerano, 1998, p. 124), despite the perfect strangeness of Ramage to the political events of the time.

${ }^{40}$ Ramage 2013, pp. 83-84.

${ }^{41}$ The meaning of the toponym "Bruca" is still obscure, but Ramage's explanation (which derives it from a nearby forest) corresponds to what was reported by Giustiniani the end of the century, ${ }^{42}$ discovering, to his detriment, that the medieval tower, used as a pigsty, was infested with fleas. A local antique dealer reveals to him the existence of a double port of the ancient city ${ }^{43}$ (later confirmed by archaeological excavations ${ }^{44}$ ) and the custom of landowners to hide, keep or resell the artefacts found at the antiques market in Naples (already famous for the sale of fakes). The following view of the so-called "tomb of Palinuro" arouses many perplexities in him instead: Ramage is not mistaken, since the Cenotaph is an ancient monument in Lucania erected to invoke the divine benevolence following pestilence (in this regard, see Greco 1975, pp. 94-95). Similarly, he notices the medieval origin of the remains of the presumed city of Melphes, on the mountain above the mouth of the river Molpa (today Lambro), as well as the stronghold of the city of Buxentum (today Policastro Bussentino), formerly a Roman colony and, earlier still, Greek, from which the Bussento river evidently gets its name. ${ }^{45}$

\section{Conclusions}

Through Ramage's diary we tried to roughly reconstruct a small geographical monograph of the Cilento before the Unification of Italy in, as much as possible, a holistic vision. Thus a direct connection emerged between the cultural isolation and the difficult relationship of the Cilentans with a hard and hostile environment, even more so because of the presence of problems and territorial fractures punctually recorded by the coeval and, in many ways, still current statistical analysis. The Cilento was in effect one of the "suburbs" of the Kingdom of Naples and Ramage experiences its state of abandonment, seeing the Cilentans deprived of the possibility of better life prospects, taking on a daily struggle for survival, from every point of view. Overcoming the initial prejudices, the Scotsman gets to the point of believing that the dangers to which his friends believed him exposed "exist only in their fervid imagination. I like everything I've seen of these people; nothing can exceed the goodness, courtesy and hospitality shown to me without distinction, by all those whom I have approached" (Ramage 2013, p. 89).

It therefore remains for us to reflect on the fact that the story of this travel experience shows the persistence of problems still existing: social marginalisation, bad roads, economic backwardness (between archaic agricultural structures and backward settlement of land), irrational exploitation of slopes,

(Reasoned Geographical Dictionary of the Kingdom of Naples, Volume III, Napoli 1797 p. 302), who writes: "I can not indicate precisely when it had lost the name of Velia, and it assumed that of Castellammare della Bruca. At the time of S. Gregorio M. it had the name of Velia; that of castle then took it from the fortress located on top of a hill [...] and the addition of Bruca from the nearby ancient forest of holm oaks, which begins with the appurtenances of Cuccaro, and ends at the ancient walls of Velia".

${ }^{42}$ After a survey carried out by Schleuning in 1889 , only in 1927 was a first excavation carried out, a campaign conducted by Maiuri and financed by the Magna Grecia Society, which was continued in 1935. Wider research began in 1950 (with Pellegrino Claudio Sestieri) while, starting from 1961 (with the excavations of Mario Napoli), a methodical and programmed excavation campaign began (see the Italian Encyclopedia Treccani, sub-item "Velia" by F. Krinzinger, G. Tocco Sciarelli [http://www.treccani.it/ enciclopedia/velia_\%28Enciclopedia-dell\%27-Arte-Antica\%29/]. Concerning this, see also De Magistris 2008 .

${ }^{43}$ Ramage (2013, p. 86), however, already sees this hypothesis confirmed in a verse of the Aeneid (VI, 366), where Virgilio writes: "Portusque require Velinos" ("to look for the ports of Velia").

${ }^{44}$ While the location of the port at the mouth of the Palistro is certain, what is less certain is that of the other port north of Velia. In this regard, see Capano 2012, pp. $159-160$, note 65 .

${ }^{45}$ Regarding the erroneous identification between Melphes and Buxentum supported among others by Baron Antonini (1745, p. 397), see Romanelli 1815, pp. 368-376, and Capano 2012, pp. 165-166. As for the origin of Bussento (whose name is "taken from an abundant plant in these places, the boxwood, in Greek pyxos, in Latin buxus, from which Buxentum": La Greca 2010, p. 21), see Natella\&Peduto 1973, pp. 483-522 (where a rich bibliography can be found); Bencivenga Trillmich 1988, pp. 701-729. 
cultural forms of an extensive type, large extension of the productive harvest.

These are hurdles aggravated by the economic changes of post-World War II, with the emigration of thousands of Cilentans and the depopulation of the internal hilly areas, the company division, the process of tourist transformation of the coastal strip, the hydrogeological instability and the inadequate management of road infrastructure, of which the internal areas suffer, often isolated for days after floods. All these circumstances still make
Cilento "a singular geographical entity closed" (Mautone 1990, p. 227 ) and "one of the weakest inland areas of the South" (Yonder $p$. 235), for which we continue to wait for sustainable development interventions (considering also the existence of the National Park of Cilento, Vallo di Diano and Alburni), accompanied by important infrastructural issues - especially of mobility/transport - of regional and interregional importance, already well identified by the Territorial Regional Plain of Campania (November 2006).

\section{References}

Acocella, N 1971, 'Il Cilento dai Longobardi ai Normanni (secol $\mathrm{X}$ e XI). Struttura amministrativa e agricola, I (L'ordinamento amministrativo), II (Agricoltura e insediamento rurale)' in Salerno medioevale ed altri saggi ['The Cilento from the Lombards to the Normans ( $\mathrm{X}$ and XI centuries). Administrative and agricultural structure, I (The administrative system), II (Agriculture and rural settlement)', in Medieval Salerno and other sages], ed. N Acocella, Libreria Scientifica Editrice, Napoli, pp. 321-487.

Alessio, G 1958, Panorama di toponomastica italiana [Panorama of Italian place names], Liguori, Napoli.

Aloia, A \& Guida, D (eds.) 2010, I Geositi: la voce della natura del Geoparco [Geosites: the voice of the nature of the Geopark]. Available from: <http://www.morigeratigeofestival.it/morigeratigeo-festival/morigerati-geo-sito.asp>. [1 October 2010].

Antonini, GA 1745, La Lucania. Discorsi di G.A. Antonini Barone di S. Biase, Parte Prima, Discorso I, II, III [Lucania. Speeches by G.A. Antonini Baron of S. Biase, Part One, Speech I, II, III], appresso Benedetto Gessari, Napoli.

Armone Caruso, A (ed.) 2000, I Rei di Stato del Principato Citra del 1799 [The offenders of State in the Citra Principality in 1799], Terra del Sole, Nocera Inferiore.

Astone, F 2012, 'Alle origini del toponimo Cilento: la fondazione di Poseidonia ed i Tirreni-Etruschi del golfo di Salerno. Riflessioni ed ipotesi', Annali Storici di Principato Citra [At the origins of the place name Cilento: the foundation of Poseidonia and the Tirreni-Etruschi of the Gulf of Salerno. Reflections and hypotheses, Historical Annals of Principality Citra], vol. X, no. 1, pp. 5-44.

Aversano, V 1982, 'Il toponimo Cilento e il centro fortificato sul Monte della Stella', Studi e Ricerche di Geografia [The toponym Cilento and the fortified center on Stella Mountain, Studies and Researches of Geography], vol. 5, no.1, pp. $1-42$.

Aversano, V 1983, 'Il Coronimo Cilento e il suo territorio (1034-1552)', Studi e Ricerche di Geografia [The regionname Cilento and its territory (1034-1552), Studies and Research of Geography], vol. 6, no. 1, pp. 78-127.

Aversano, V 1987, 'Sul sito di alcuni «villages désertés» del Principato: riflessioni geografiche', in Salerno e il Principato Citra nell'età moderna (secoli XVI-XIX), Atti del Convegno di Studi [About the site of some "villages désertés" of the Principality: geographical reflections, Proceedings of the Study Conference], ed. F Sofia, Salerno, Castiglione del Genovesi, Pellezzano, 5-7 dicembre 1984, Pubblicazione dell'Università degli Studi di Salerno, Sez. atti, convegni, miscellanee, 17, Napoli, pp. 307-350.

Aversano, V 1989, 'Aspetti geografici del territorio cilentano', in Storia delle Terre del Cilento antico [Geographical aspects of the Cilento territory, in History of the lands of ancient Cilento], ed. P Cantalupo \& A La Greca, Centro di Promozione Culturale per il Cilento, Agropoli, pp. 27-36.

\section{Aversano, V 2009a, 'Introduzione', in II territorio del Cilento nella} cartografia e nella vedutistica. Secc. XVII-XIX [Introduction, in The territory of Cilento in the cartography and in the painting landscape. XVII-XIX centuries], ed. V Aversano, Palazzo Vargas Edizioni, Vatolla, pp. 13-14.

Aversano, V 2009b, II territorio del Cilento nella Cartografia (secc. XVI-XIX), in II Territorio del Cilento nella Vedutistica e nella Cartografia... cit. [The territory of Cilento in the Cartography (16th-19 $9^{\text {th }}$ centuries), in The territory of Cilento in the cartography and in the painting landscape... mentioned], ed. V Aversano, Palazzo Vargas Edizioni, Vatolla, pp. 19-107.

Aversano, V \& Siniscalchi, S 2008, 'Una fonte trascurata per la ricostruzione del paesaggio e dell'identità territoriale: $\mathrm{i}$ toponimi di antiche carte regionali come caso dimostrativo', in Scritti in onore di Carmelo Formica [A neglected source for the reconstruction of the landscape and of the territorial identity: the place names of ancient regional maps as a demonstration case, in Papers in honor of Carmelo Formica], ed. N Castiello, Università degli Studi di Napoli "Federico II", Dip. di Analisi dei processi ELPT, Sezione Scienze Geografiche, Napoli, pp. 49-87.

Bencivenga Trillmich, C 1988, 'Pyxous-Buxentum', Mélanges de l'Ecole française de Rome. Antiquité, vol. 100, no. 2, pp. 701-729.

Camporeale, G 1961, 'Melpo e Melfi', Studi Etruschi [Melpo and Melfi, Etrurian Studies], vol. XXIX, pp. 219-231.

Cantalupo, P 1989, 'Schede-Centri viventi e scomparsi', in Storia delle terre del Cilento antico [Forms-Living and disappeared centers in History of the lands of the ancient Cilento], eds. P Cantalupo \& A La Greca, Edizioni del Centro di promozione culturale per il Cilento, Acciaroli, vol. II, pp. 672-674 and 698-702.

Cantile, A 2013, Lineamenti di storia della cartografia italiana [Tendencies of the history of Italian cartography], Rubbettino, Soveria Mannelli.

Capano, A (ed.) 2001, // Cilento e il mare [The Cilento and the sea], Pro Loco "Agropoli Turistica", Agropoli, pp. 18-23.

Capano, A 2012, "Una interessante "guida" manoscritta del Cilento (1784)', Annali Storici di Principato Citra [An interesting manuscript "guide" of Cilento (1784), Historical Annals of Principality Citra], vol. X, no. 2, pp. 140-184.

Carucci, C 1937, 'Documenti sul 1799 nel Cilento', Rassegna Storica Salernitana [Documents about 1799 in Cilento, Historical Review of Salerno], vol. I, no. 1, pp. 162-168.

Colletta, P 1861, Storia del Reame di Napoli dal 1734 al 1825 [History of the Kingdom of Naples from 1734 to 1825], Enrico De Angelis Librajo-Editore, Napoli, vol. II.

D'Amico, G (ed.) 2001, II mito di Velia e il fascino del Grand Tour [The myth of Velia and the charm of the Grand Tour], Impronta Italia Edizioni, Salerno.

D’Arienzo, V 1991a, 'La regia dogana del sale di Policastro. Alcuni aspetti della distribuzione forzosa nel Cilento, Vallo 
di Diano e Lucania nel XV secolo', Annali Cilentani [The customs duties of salt in Policastro. Some aspects of the forced distribution in the Cilento, Vallo di Diano and Lucania in the XV century, Annals of Cilento], vol. 111, no. 2, pp. 3-24.

D'Arienzo, V 1991b, 'Immissioni di sale nel porto di Salerno nella seconda meta del XVII secolo', Bollettino Storico di Salerno e Principato Citra [Salt insertions in the port of Salerno in the second half of the seventeenth century, Historical Bulletin of Salerno and Principality Citra], vol. 9, no. 2, pp. 65-74.

De Magistris, E 2008, 'Cronologia e funzione di porta Rosa a Velia', Orizzonti [Chronology and function of the Rosa Gate in Velia, Horizons], vol. 9, pp. 48-58.

De Marco, D (ed.) 1988, La statistica murattiana del Regno di Napoli nel 1811 [The Murat's statistic of the Kingdom of Naples in 1811], Accademia nazionale dei Lincei, Roma, vol. IV.

De Sanctis, G 1840, Dizionario Statistico de' paesi del Regno delle Due Sicilie [Statistical Dictionary of the countries of the Kingdom of the Two Sicilies], Dalla Stamperia e Cartiere del Fibreno, Napoli.

De Seta, C 1982, 'L'Italia nello specchio del Grand Tour', Storia d'Italia. V, II paesaggio [Italy in the mirror of the Grand Tour, History of Italy. V. The landscape], Einaudi, Torino, pp. 127-264.

Fasano, P 2007, 'Letteratura di viaggio' in Enciclopedia Italiana Treccani, VII, Appendice [Travel literature, in Italian Encyclopedy Treccani, VII, Appendix]. Available from: <http://www.treccani.it/enciclopedia/letteratura-diviaggio_\%28Enciclopedia-Italiana\%29/>. [10 April 2018].

Ferrari, A 2010, 'Luoghi senza nome e nomi senza luogo nella mitologia classica', in XXII Congresso Internazionale di Scienze Onomastiche [Places without names and names without place in classical mythology, in XXII International Congress of Onomastic Sciences], Proceedings (Pisa, 28/08-04/09/2005), eds MG Arcamone, D Bremer Buono, D, De Camilli \& B Porcelli, ETS, Pisa, vol. VIII, pp. 383-391.

Ebner, P 1973, Economia e società nel Cilento medievale [Economy and society in the Cilento of Middle Age], Edizioni di Storia e Letteratura, Roma, 2 books.

Ebner, P 1982, Chiesa, Baroni e popolo nel Cilento [Church, Barons and people in Cilento], ETS, Roma, 2 books.

Frémont, A 2007, Vi piace la geografia? [Do you like geography?], ed. D Gavinelli, Carocci, Roma.

Galotti, A \& Galzerano, G 1998, Le "memorie" di Antonio Galotti: la rivolta del Cilento del 1828 [The "memories" of Antonio Galotti: the revolt of the Cilento in 1828], Galzerano, Casalvelino.

Giosuè, D 2004, Viaggiatori inglesi in Italia tra Cinque e Seicento [British travelers in Italy between the fifteenth and seventeenth centuries], Sette Città, Viterbo. Available from: <http://dspace.unitus.it/bitstream/2067/57/1/giosue _ viaggiatori_inglesi.pdf>. [12 April 2018].

Greco, E 1975, 'Velia e Palinuro. Problemi di topografia antica', Mélanges de l'Ecole française de Rome. Antiquité [Velia and Palinuro. Problems of ancient topography, Mixtures of the French school of Rome. Antiquities], vol. 87, no. 1, pp. 81-142.

La Greca, F (ed.) 2002, Fonti letterarie greche e latine per la storia della Lucania tirrenica [Greek and Latin literary sources for the history of Tyrrhenian Lucania], L'Erma di Bretschneider, Roma.

La Greca, F 2010, 'L'area del Golfo di Policastro in epoca grecoromana', in Temi per una storia di Torraca [The area of the Gulf of Policastro in the Greek-Roman period, in Themes for a story of Torraca], eds F La Greca, A La Greca, A, Capano, \& A Migliorino, Centro di Promozione Culturale per il Cilento, Acciaroli, pp.17-44.
La Greca, F 2012, 'Paestum e il suo territorio nella cartografia storica medioevale e moderna', Annali Storici di Principato Citra [Paestum and its territory in medieval and modern historical cartography, Historical Annals of Principality Citra], vol. X, no. 1, pp. 45-95.

La Greca, F 2014, 'Noterelle Pestane I-I porti di Paestum nel medio evo ed una ipotesi sul porto romano', Annali Storici di Principato Citra [Small notes of Paestum I-The ports of Paestum in the Middle Ages and a hypothesis on the Roman port, Historical Annals of Principality Citra], vol. XII, no. 1, pp. $33-59$

Lassels, R 1670, The Voyage of Italy, or, A Compleat Journey through Italy, John Starkey, London.

Mautone, M (ed.) 1990, 'La costiera cilentana', in Campania. Scenari geografici di uno sviluppo discontinuo [The Cilento coast, in Campania. Geographic scenarios of a discontinuous development], ed. ML Gasparini, Studio Eikon, Napoli, pp. 227-262.

Mazzetti, E 2008a, 'La relazione di viaggio come testimonianza dell'esperienza odeporica, filtro interpretativo e fonte del sapere geografico', in Scenari del Sud di ieri e di oggi [The travel report as a testimony to the same experience, interpretative filter and source of geographical knowledge, in Southern scenarios of yesterday and today], eds E Mazzetti \& D Russo Krauss, Guida Editori, Napoli, pp. 29-38.

Mazzetti, E 2008b, 'Viaggiatori, visitatori, imprenditori alla scoperta del Sud Italia nell'età del Grand Tour', Scenari del Sud di ieri e di oggi [Travelers, visitors, entrepreneurs to discover Southern Italy in the age of the Grand Tour, Southern scenarios..., mentioned], pp. 63-78.

Mazzetti, E 2008c, 'L'immagine della città del Sud dalle assonometrie alla pittura di paesaggio', Scenari del Sud di ieri e di oggi [The image of the southern city from axonometry to landscape painting, Southern scenarios..., mentioned], pp. 39-62.

Mozzillo, A 1992, La frontiera del Grand Tour [The frontier of the Grand Tour], Liguori, Napoli.

Muratori, L 1739, Antiquitates Italicae Medii Aevi, Tomus Secundus, Ex Typographia Societatis Palatinae, Milano.

Natella, P \& Peduto, P 1973, 'Pyxous-Policastro', L'Universo, vol. 53, pp. 483-522.

Oliva, G 2012, Un regno che è stato grande [A kingdom that was great], Mondadori, Milano.

Pagano, G 1853, Storia di Ferdinando II: Re del Regno delle Due Sicilie. Dal 1830 al 1850 [History of Ferdinando II: King of the Kingdom of the Two Sicilies. From 1830 to 1850], Book I, Dalla Tipografia di B. Cannavacciuoli, Napoli.

Preziosi, G (ed.) 1990, 'Il Cilento storico', in Campania. Scenari geografici... cit. [The historic Cilento, in Campania. Geographic scenarios... mentioned], ed. ML Gasparini, pp. 209-226.

Quaini, M 2006, L'ombra del paesaggio. Orizzonti di un'utopia colloquiale [The shadow of the landscape. Horizons of a colloquial utopy], Diabasis, Reggio Emilia.

Raffestin, C 2005, Dalla nostalgia del territorio al desiderio di paesaggio. Elementi per una teoria del paesaggio [From the nostalgia of the territory to the desire for a landscape. Elements for a landscape theory], Alinea, Firenze.

Ramage, CT 1966, Viaggio nel Regno delle Due Sicilie [Journey into the Kingdom of the Two Sicilies], ed. E Clay, De Luca, Roma.

Ramage, CT 2013, Attraverso il Cilento. I/ viaggio di C.T. Ramage da Paestum a Policastro nel 1828 [Through the Cilento. The journey of C.T. Ramage from Paestum to Policastro in 1828], Edizioni dell'Ippogrifo, Cava de' Tirreni. 
Romanelli, D 1815, Antica Topografia Istorica del Regno di Napoli [Ancient Historic Topography of the Kingdom of Naples], Nella Stamperia Reale, Napoli, Parte I.

Rousseau, JJ 2012, Le passeggiate del sognatore solitario [The solitary dreamer's walks], Sebaste, Feltrinelli, Milano.

Ruocco, D (ed.), 2010, 'Emozioni-Territori emotivi-Geografia emozionale. Precisazioni concettuali', Studi e Ricerche socio-territoriali [Emotions-Emotional Territories-Emotional Geography. Conceptual specifications, in Socio-territorial studies and research], Napoli, vol. 10, pp. 19-20.

Scaramellini, G 2008, Paesaggi di carta, paesaggi di parole. Luoghi e ambienti geografici nei resoconti di viaggio (secoli XVIII-XIX) [Landscapes of paper, landscapes of words. Places and geographical environments in travel reports (XVIII-XIX centuries)], Giappichelli, Torino.

Schiarini, P 2007, "Alfano Raffaele" in Dizionario del Risorgimento Nazionale (Dizionario Rosi) [Dictionary of the National Risorgimento (Rosi Dictionary)] Available from: <https://web.archive.org/web/20080421021841/http://www. dizionariorosi.it> [20 May 2007].

Sestini, A 1963, II paesaggio [The landscape], T.C.I., Milano 1963.

Siniscalchi, S 2008, 'L'identità svelata. Un esempio d'indagine geografico-storica sul Cilento attraverso la toponomastica' (secc. XVII-XIX) [Identity unveiled. An example of a geographic-historical survey on the Cilento through the place names (17th-19th centuries)], Geotema, vol. 34, pp. 78-87.

Siniscalchi, S 2012, Rappresentazione, percezione, territorio. II rebus gnoseologico-applicativo delle carte geografiche [Representation, perception, territory. The gnoseological-applicative rebus of geographical maps], Aracne, Roma.

Tosco, C 2007, Il paesaggio come storia [The landscape as history], II Mulino, Bologna.

Turri, E 2002, La conoscenza del territorio. Metodologia per un'analisi storico-geografica [Knowledge of the territory. Methodology for a historical-geographical analysis], Marsilio Editori, Venezia.

Turri, E 2004, Il paesaggio e il silenzio [The landscape and the silence], Marsilio Editori, Venezia.

Valerio, V 1993, Società, uomini e istituzioni cartografiche nel Mezzogiorno d'Italia [Society, men and cartographic institutions in Southern Italy], Istituto Geografico Militare, Firenze.

Vallega, A 2004, Le grammatiche della geografia [The grammars of geography], Pàtron, Bologna. 